\title{
Design and Fabrication of a Novel Hybrid Solar Distillation System with the Ability to Brine Recycling
}

\author{
Arash Ranjbaran*, Mahdi Norozi \\ Department of Mechanical Engineering, Islamic Azad University, Ilkhchi Branch, Iran
}

Corresponding Author Email: ranjbaranarash@gmail.com

https://doi.org/10.18280/ijht.370311

Received: 3 September 2018

Accepted: 19 March 2019

\section{Keywords:}

cascade solar still, hybrid solar distillation, parabolic trough collector, recycling brine, heat transfer, solar energy

\begin{abstract}
This study investigates the novel design of a hybrid solar distillation system. The system includes a parabolic trough collector (PTC), cascade solar still and a single slope single basin solar still as the recycling unit. Thermodynamic parameters of saline water were considered in our energy balance calculations, which improved the accuracy of our results. The experiments were conducted in Tabriz, Iran, during September. Using these three stages, the production rate achieved about $6 \mathrm{~kg} / \mathrm{m}^{2}$.day in cascade solar still, $4 \mathrm{~kg} / \mathrm{m}^{2}$.day for the single basin solar still and $450 \mathrm{~g}$ solid salt. Usually, cascade solar stills have better performance in comparison to other solar stills. To prevent salt deposition among the stairs of cascade solar still, the water should flow through the stairs causing the brine to leave. Recycling brine could remove one of the biggest environmental disadvantages of cascade solar stills. PTC can generate more efficiently than evacuated tubes and flat-plate solar collectors. The total efficiency of the hybrid solar distillation reached $41 \%$. The novel hybrid solar distillation system improved the efficiency of the distillation system and removed brine of cascade solar still.
\end{abstract}

\section{INTRODUCTION}

Water shortages and population growth in coastal urban areas have increased the need for fresh water resources in the world. Many countries use various desalinations as a solution for water scarcity. The brine of water desalination causes severe pollution to the environment, and the carbon diffusion of the desalination process is another important problem. The use of membrane technology and renewable energy to produce fresh water are offered as alternatives to polluting industries. Moungar et al. [1-2], studied the effect of fine in double slope still and the simple solar distiller; they found using fins increased in the distillate quantity. However, water mass decreased in productivity.

The use of solar energy depends on the seasons, the distance from the equator, tilt angle, height, cloudiness, air, and the azimuth angle. In some places close to the sea, especially in the Middle East, a small amount of freshwater is critical conditions. Therefore, the usage of solar still is a great idea in the discussion of seawater distillations. Sathyamurthy et al. [3] investigated on conventional single slope solar still with sand heat energy storage for improving the yield of fresh water. The productivity rate from the solar still with and without energy storage materials was found to be 5.1 and $1.9 \mathrm{~kg} / \mathrm{m}^{2}$.day, respectively. The thermal performance of the single slope solar still is evaluated by the following effective parameters such as insulation thicknesses, solar intensity, overall heat loss, and effective absorptivity and transmissivity coefficient [4]. Sadaghiyani et al. [5] presented theoretical modeling of a parabolic collector with computational fluid dynamics (CFD); they reported that using evacuated tube leads to increasing of exergy from 10 to 60 percent; the low depth of water and radiation improved the performance of solar still. In terms of solar collectors, parabolic trough collectors (PTC) are widely used. Their efficiencies are about 60-80\%; To use the high efficiency of these collectors, they should be combined with the systems used. Tiwari et al. [6] studied an active solar distillation where a flat solar collector combined with a solar still; they reported that the optimum depth and thickness of insulation for active solar still was $0.11 \mathrm{~m}$ water depth and 0.03 $\mathrm{m}$ for insulation. Rajanand Patnaik et al. [7-8] studied multilevel power converter and comparative analysis of various MPPT (maximum power point tracking) on renewable energies sources especially solar energy; using these techniques in designing solar systems can improve system efficiency.

Behar et al. [9] showed that the use of the glass envelope in the focal tube of PTC within the vacuum could transfer more heat to the working fluid. Sathyamurthy et al. [10] experimentally investigated the use of a sand heat energy storage in conventional single slope solar still for improving the yield of fresh water. Norozi [11] presented modified stepped solar still with hourly sun tracking on cascade solar still. They have carried out a comparison between the fixed stepped and tracking solar still; the results showed energy efficiencies increased significantly than the fixed. Tabrizi et al. [12-13], and Velmurugan et al. [14] examined the stepped solar still and showed that the performance of this model $20 \%$ better than an SBSS. The average production of stepped systems is $4-7 \mathrm{~kg} / \mathrm{m}^{2}$; cleaning the deposited salt from its stairs is difficult. Also, due to the imbalance of levels, creating a thin layer of water on the channels is very difficult. To solve these problems, Tabrizi used a flow rate to prevent salt deposition and weir. But the outflow of brine from the device will be very salty and cause harm to the environment. The brine concentration in the final stages of distillation reaches 120 $350 \mathrm{~g}$ of salt per liter, which is a high brine concentration. Latent evaporation heat in the salinity has about a 10 percent 
difference with water. Purpose of the paper is studied, reducing the preheating time in cascade solar still and introducing an efficient solution to the problem of wastewater (brine) of the cascade solar stills; the effect of salt and other parameters of saline water were considered, in the solar still energy calculations.

\section{DESCRIPTION OF THE SYSTEM}

In this experiment, was used a parabolic trough collector
(PTC) with a low vacuum condition (vacuum $<500$ mbar), cascade solar still and a single slope basin still; Figure 1 is a schematic model designed for water distillation. In the first stage, saline water enters the PTC. The water temperature rises to the threshold of the change phase in the liquid phase and with the highest enthalpy flows to the stepped distillation. Direct solar evaporation of energetic saline water is done much easier at this stage because the internal energy for evaporation has been greatly increased. At a temperature of $60-90{ }^{\circ} \mathrm{C}$, the molecules of water are at a high level of energy and are in the low depth of stepped distillation.

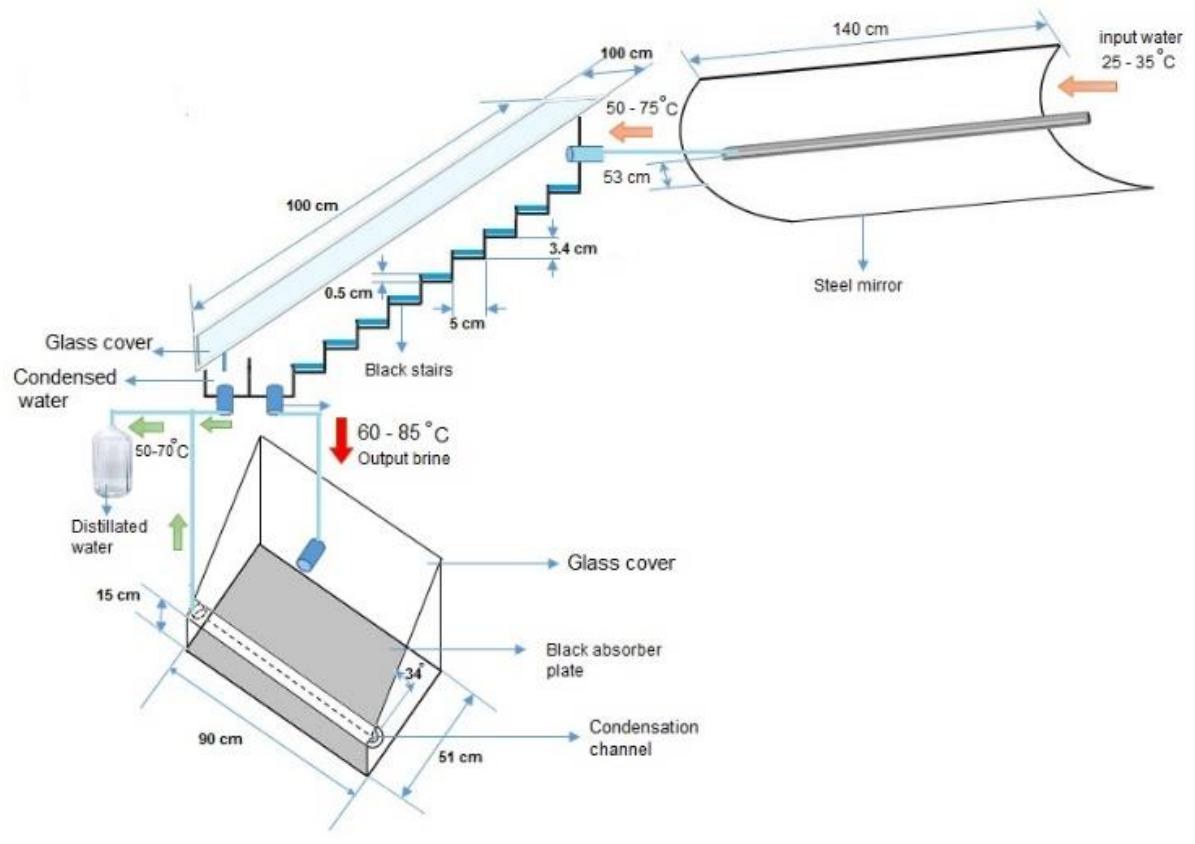

Figure 1. Fabricated hybrid solar distillation system

Preheated saline water quickly evaporates, and it flows on the stairs, it absorbs solar energy by increasing its internal energy. In the second stage, to prevent salt deposition in distillation stairs, the average flow rate was chosen based on that the remaining saline water in the channels does not reach the saturation state of the salt. In this stage, about $20 \%$ of the input fluid passes to the third stage as brine for recycling. The brine must be completely evaporated on the same day, and the solid salt should be collected. Solid salt can be stored dry to be used for animal husbandry or industry. Therefore no more water should enter the PTC one hour earlier than the end of the solar peak hours (solar peak hours is the average of 6 hours around 10 am to $4 \mathrm{pm}$ ). All the water in the recycling system evaporates on the same day. Therefore, this would that solid salt can be collected without environmental pollution.

\section{THERMODYNAMIC SEAWATER}

\section{PARAMETERS}

OF

Most theoretical energy analysis and calculations of the solar stills carried out based on pure water, but the real fluid in use is salt water. We used saline water at 35 grams of salt per liter. During the evaporation of saline water in the still, salt concentration increases. At the end of the stairs of the proposed model, the salt concentration reaches 120-200 gram per liter. Based on the results presented by Sharqawy et al. [15], there is a $10 \%$ difference between the latent heat of vaporization of salted water (salt concentration of $120 \mathrm{~g} / \mathrm{L}$ ) with pure water; according to their reported results, the specific heat of saline water in $20{ }^{\circ} \mathrm{C}$ with salinities of 20,40 and $120 \mathrm{~g} / \mathrm{kg}$ was $4.1,4$ and $3.6 \mathrm{~kJ} / / \mathrm{kg}$. K respectively. And latent heat of saline water was 2420,2380 and $2150 \mathrm{~kJ} / \mathrm{kg}$; for the pure water latent and specific heat was $2460 \mathrm{~kJ} / \mathrm{kg}-4.2$ $\mathrm{kJ} / \mathrm{kg}$. K respectively.

\section{ENERGY ANALYSIS}

\subsection{Parabolic trough collector (PTC)}

The constant temperature output of fluid can't be maintained with a constant flow rate in the parabolic collector [18]. Bakos [19] could get energy up to $35 \mathrm{MJ}$, with a maximum radiation intensity of $1010 \mathrm{~W} / \mathrm{m}^{2}$ and a dual-axis tracker $/ \mathrm{m}^{2}$ in Cyprus. Muhammad [20] showed maximum fluid temperature of PTC reached an average of $65^{\circ} \mathrm{C}$, where the radiation rate was $1000 \mathrm{~W} / \mathrm{m}^{2}$ and the mass flow was 0.005 $\mathrm{kg} / \mathrm{s}$; his non-linear equation had the capability to estimate the temperature of the fluid in the pipe in comparison with the experimental results within a $10 \%$ error margin. Ghassemi et al. [21] evaluated the effect of nanoparticles on the mean output temperature of PTC. The nanofluid was $\mathrm{Cu}$-Water where the particle volume fraction was $0.02 \%$; the fluid velocity was $1.5 \mathrm{~mm} / \mathrm{s}$, the air temperature was $25^{\circ} \mathrm{C}$, the length of PTC was 2 meters, and the solar radiation flux was 
$1000 \mathrm{~W} / \mathrm{m}^{2}$. They showed an output temperature increase of $10{ }^{\circ} \mathrm{C}$.

The energy equation of receiver element and transient performance is given by [20]:

$$
\begin{gathered}
\frac{\partial T_{r}}{\partial_{t}}-a_{r} \frac{\partial^{2} T_{r}}{\partial x^{2}}= \\
\frac{D_{r o} C F_{r} \tau_{c o v r} a b_{r} \tau_{c p c} \gamma I_{0}-\alpha_{r f} D_{r i}\left(T_{r}-T_{f}\right)-\alpha_{r g} D_{r o}\left(T_{r}-T_{g}\right)}{\left(\frac{D_{r o}^{2}-D_{r i}^{2}}{4}\right) \rho_{r} C_{r}} \\
\eta_{t h}=\frac{\dot{m} C_{f}\left(T_{f o}-T_{f i}\right)}{A_{a p} I_{0}}
\end{gathered}
$$

where, $\gamma$ and $\tau_{c p c}$ are diffuse radiation and effective transmissivity of the PTC, respectively. For the pure cylindrical focal tube of the PTC, $\gamma=1$. The size parameter $\alpha$ was defined as follows [22]:

$$
\alpha=\frac{\pi D}{\lambda}
$$

where, D is the perfect diameter for a parabolic collector. Figure 2 presents a cross-section of the receiver and reflector showing different angles and a heat transfer model of PTC. The aperture of the parabola $\left(W_{a}\right)$ and the geometric concentration ratio of the tubular absorber $(\mathrm{C})$, is expressed as follows:

$$
\begin{aligned}
D & =2 r_{r} \sin \theta_{m} \\
r & =\frac{2 f}{1+\cos \theta} \\
W_{a} & =4 f \tan \left(\frac{\theta_{r}}{2}\right) \\
& =\frac{\sin \theta_{r}}{\pi \sin \theta_{m}}
\end{aligned}
$$

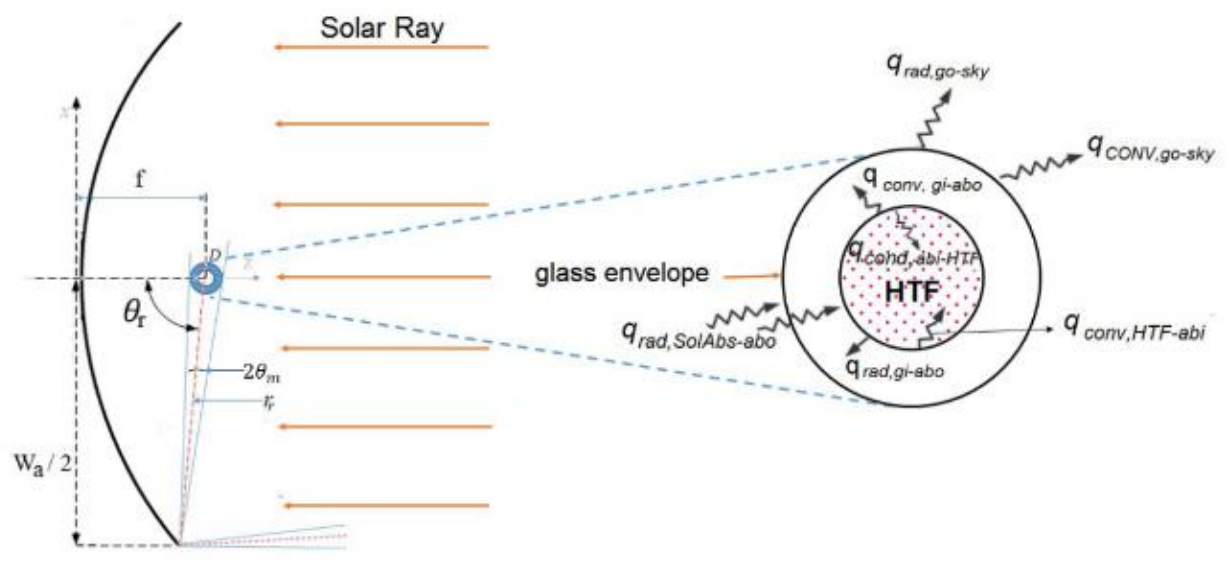

Figure 2. A cross section of the receiver and reflector showing different angles and heat transfer model

\subsection{Thermal model}

These models are investigated based on the energy balance of the concentration of radiant energy of PTC. A glass envelope of the focal tube can prevent $2-40 \%$ of the pipes heat loss. It depends on high thermal fluid (HTF) temperature and system conditions. However, the pipe temperature depends on environmental conditions. Usually, these heat losses in the water distillation systems are lower than in the power systems because the maximum temperature is around $60-90{ }^{\circ} \mathrm{C}$.

The general equations of energy balance for PTC were as follows [22]:

$$
\begin{gathered}
\dot{q}_{c o n v . a b i-H T F}=\dot{q}_{\text {cond.abo-abi }} \\
\dot{q}_{\text {SolAbs.abo }}=\dot{q}_{\text {conv.abo-gi }}+\dot{q}_{\text {rad.abo-gi }}+\dot{q}_{\text {cond.abo-abi }} \\
\dot{q}_{\text {conv.abo-gi }}+\dot{q}_{\text {rad.abo-gi }}=\dot{q}_{\text {cond.gi-go }} \\
\dot{q}_{\text {cond.gi-go }}+\dot{q}_{\text {SolAbs.go }}=\dot{q}_{\text {conv.go-a }}+\dot{q}_{\text {rad.go-sky }} \\
\dot{q}_{\text {heat loss }}=\dot{q}_{\text {conv.go-a }}+\dot{q}_{\text {rad.go-sky }}
\end{gathered}
$$

Thermal efficiency $(\eta)$ of the PTC defined as follows [23]:

$$
\eta=\frac{m c_{p}\left(T_{f o}-T_{f i}\right)}{D N I A_{a}}
$$

For optical efficiency $\left(\eta_{o . n}\right)$ adapted from the ASHRAE Standard 93-2010 can be written [23]:

$$
\eta_{o . n}=[(\tau \alpha) \rho \gamma]_{n}\left(1-A_{f . n}\right)
$$

where, $(\tau \alpha)$ is the transmittance - absorbance, $\rho$ is the specular reflectance of the parabolic mirror, $\gamma$ is the intercept factor and $A_{f}$ is the ratio of ineffective area depending on geometrical effects.

For the numerical calculation of heat transfer in a PTC pipe wall, the bulk temperature method has been used $(\mathrm{Re}<2300)$ [24]. In this experiment, the average temperature of the tube wall was considered to be fixed; the heat flux was also fixed while the tube temperature was a variable. The Nusselt number will be obtained from the following equation [24]:

$$
\overline{N u}_{d}=1.86\left(\operatorname{Re} e_{d} \operatorname{Pr}\right)^{1 / 3}\left(\frac{d}{L}\right)^{1 / 3}\left(\frac{\mu}{\mu_{w}}\right)^{0.14}
$$

where, $\mu_{w}$ is the viscosity depending on the tube's temperature, $\mathrm{D}$ is the tube's diameter, and $\mathrm{L}$ is the length of the tube. It can be mentioned that According to Incropera equations, Nusselt can be given as $(\mathrm{Nu})=4.36$ [25]. The difference between the results of Nusselt obtained from equation (13) with Incropera equations is negligible. 


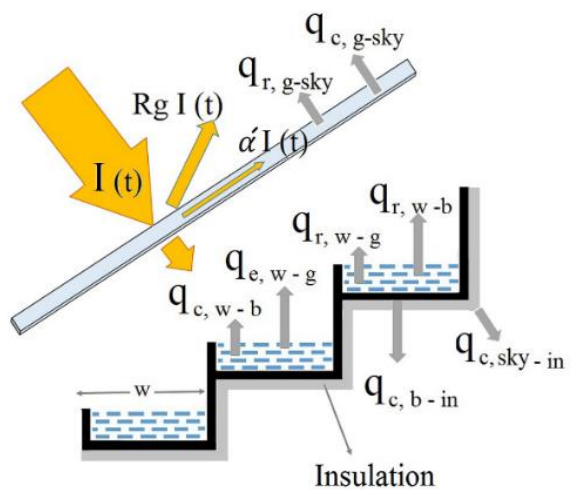

Figure 3. A cross sectional thermal model of cascade solar still

\subsection{Cascade and single basin solar still}

Energy equations of cascade solar still are similar to single basin solar still. Each stair of cascade solar still can be simulated as a single basin solar still. According to the models shown in Figures 4 and 5, for better management, the flow rate is considered fixed at the entrance of PTC. Because of the change in evaporation rate, the flow rate of the output fluid from the cascade solar still will be variable. However, the average amount of radiation will be almost constant. The thermal losses were calculated by analyzing the experimental results of Tiwari [29-31] who designed an active solar distillation which was coupled single basin slop solar still with the parabolic collector (PTC). Tabrizi $[13,26]$ offered some equations for the calculation of energy balance in cascade solar still.

The energy balance for the output brine on each stair can be written as [29]:

$$
\begin{gathered}
q_{a b s . w}+\dot{m}_{i} h_{i}-\left(q_{r . w}+q_{c . w}+q_{e . w}+q_{l . w}\right)-\dot{m}_{o} h_{o}= \\
\left(\rho V-\dot{m}_{e} d t\right) C_{w} \frac{d T_{w}}{d t}
\end{gathered}
$$

The energy balance for the glass cover [29, 35]:

$$
\begin{gathered}
I(t)_{s} \alpha_{g}+h_{t . w-g}\left(T_{w}-T_{g}\right)=h_{t . g-a}\left(T_{g}-T_{a}\right)+ \\
h_{r . g-s}\left(T_{g}-T_{s}\right)+\frac{M_{g} C_{g}}{A_{g}} \frac{d T_{g}}{d t}
\end{gathered}
$$

And for brackish water (saline water) [35]:

$$
\begin{gathered}
I(t)_{s} \tau_{g} \alpha_{w}+h_{w}\left(T_{b}-T_{w}\right)=h_{t . w-g}\left(T_{w}-T_{g}\right)+ \\
\frac{M_{w} C_{w}}{A_{w}} \frac{d T_{w}}{d t}
\end{gathered}
$$

For the absorber plate, received energy is equal to the energy lost to water and ambient $[35,39]$ :

$$
\begin{gathered}
I(t)_{s} \tau_{g} \alpha_{b} \tau_{w}=h_{w}\left(T_{b}-T_{w}\right)+U_{b}\left(T_{b}-T_{a}\right)+ \\
\frac{M_{b} C_{b}}{A_{b}} \frac{d T_{b}}{d t}
\end{gathered}
$$

In the next step of cascade solar still and in the next time, condensation temperature parameters, the total flux on an inclined surface and heat transfer between glass and water are expressed as following $[33,32]$ :

$$
T_{w}=T_{w}+d T_{w}
$$

$$
\begin{gathered}
T_{g}=T_{g}+d T_{g} \\
T_{b}=T_{b}+d T_{b} \\
\left(d m_{c} / d_{t}\right)=h_{e . w-g}\left(T_{W}-T_{g}\right) /\left(h_{f g}\right)
\end{gathered}
$$

where, $h_{e . w-g}$ and $h_{f g}$ are the evaporation heat transfer coefficients between saline water and glass; latent heat evaporation, respectively. For the total radiation on an incident surface $[42,43]$ :

$$
I(t)=\left(I_{g}-I_{d}\right)\left(\cos \theta_{i} / \cos \theta_{h}\right)+I_{d}(1+\cos \beta) / 2
$$

where, $I(t)$ is the solar flux on an incident collector $\left(\mathrm{W} / \mathrm{m}^{2}\right), I_{g}$ is the hourly global radiation, $I_{d}$ is the hourly diffuse radiation, $\beta$ is the tilt angle, and $\theta$ is the zenith angle.

$$
\begin{array}{r}
Q_{c . b-w}=h_{c . b-w}\left(T_{b}-T_{w}\right) \\
Q_{\text {loss }}=U_{b} A_{b}\left(T_{b}-T_{a}\right)
\end{array}
$$

$Q_{c . b-w}$ is the convection heat transfer between the basin and saline water.

$$
\begin{gathered}
Q_{c . w-g}=h_{c . w-g} A_{W}\left(T_{w}-T_{g}\right) \\
h_{c . w-g}=0.884\left\{\left(T_{w}-T_{g}\right)+\frac{\left[P_{w}-P_{g}\right]\left[T_{w}+273.15\right]}{\left[268.9 \times 10^{3}-P_{w}\right]}\right\}^{1 / 3}
\end{gathered}
$$

$h_{c . w-g}$, based on the internal heat and mass transfer relations used by Dunkel [41]. The rate of the radiation of heat transfer between saline water and glass is given by $[14,35,39]$ :

$$
\begin{gathered}
Q_{r . w-g}=h_{r . w-g} A_{W}\left(T_{w}-T_{g}\right) \\
h_{r . w-g}=\epsilon_{e q} \sigma\left[\left(T_{w}+273\right)^{2}+\left(T_{g}+273\right)^{2}\right]\left(T_{w}+T_{g}+\right. \\
\varepsilon_{e q}=\left(1 / \varepsilon_{w}+1 / \epsilon_{g}-1\right)^{-1} \\
h_{e . w-g}=\left(16.273 \times 10^{-3}\right) h_{c . w-g}\left(p_{w}-p_{g}\right) /\left(T_{w}-T_{g}\right)
\end{gathered}
$$$$
\text { 546) (30) }
$$

where, $h_{r . w-g}, \varepsilon_{e q}$ are the radiation heat transfer coefficients and emissivity, respectively. The rate of the radiation heat transfer and the convection heat transfer from glass to the sky is calculated by following equations [14, 35, 39]:

$$
\begin{gathered}
Q_{r . g-s k y}=h_{r . g-s k y} A_{g}\left(T_{g}-T_{s k y}\right) \\
\epsilon \sigma\left[\left(T_{g}+273\right)^{4}-\left(T_{s k y}+273\right)^{4}\right] /\left(T_{g}-T_{s k y}\right) \\
T_{s k y}=T_{a}-6 \\
Q_{c . g-s k y}=h_{c . g-s k y} A_{g}\left(T_{g}-T_{s k y}\right) \\
h_{c . g-s k y}=2.8+3.0 \mathrm{~V}
\end{gathered}
$$

The cover glass temperature of cascade solar still is defined as [43]: 


$$
\begin{gathered}
Q_{\text {evap }}=0.85\left(T_{m}-T_{g}\right) \varphi \\
\varphi=\frac{P_{v}}{P_{\text {sat }}} \\
P=P_{a}+P_{v}
\end{gathered}
$$

where, $T_{m} \cdot T_{g}$ are the temperature of the air-vapor mixture and the glass respectively, $\varphi$ is relative humidity; $P_{s a t}$ is the saturation pressure $(\mathrm{Pa}), P_{v}$ is vapor pressure $(\mathrm{Pa}), P_{a}$ is air pressure and $\mathrm{P}$ is total pressure. $\left(P_{\text {sat }}=P\left(T_{m}\right)\right)$. To be more precise in $\mathrm{h}_{\text {c.g-sky }}$, the laminar flow type or turbulent blowing should be determined on the glass, then Nusselt is calculated. The results lead to $h_{\text {c.g-sky }}$. Then, $R e<2300$ with the presupposition of constant heat flux [24]:

$$
\begin{gathered}
N u_{x}=\frac{h_{x}}{K}=0.452 \operatorname{Re}_{x}^{1 / 2} \operatorname{Pr}^{1 / 3} \\
h_{c . g-s k y} \cong h=2 h_{x}
\end{gathered}
$$

The overall thermal efficiency for passive solar still is Ref. [35]:

$$
\eta_{\text {passive }}=\frac{\sum m_{e w} \times h_{f g}}{\sum I(t)_{S} \times A_{S} \times 3600}
$$

And for active solar still is:

$$
\eta_{\text {active }}=\frac{\sum m_{e w} \times h_{f g}}{\sum I(t)_{s} \times A_{S} \times 3600+\sum I(t)_{c} \times A_{c} \times 3600}
$$

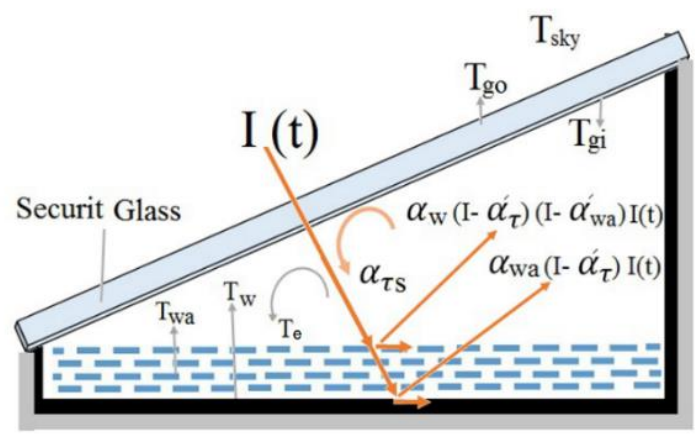

Figure 4. A cross sectional thermal model of single basin solar still (Recycling unit)

\section{RECYCLING UNIT}

Recycling unit is formed from a single basin solar still that has the capability of evaporation of all brine entering from the previous part, on the same day shown in figures 1 and 4 . The deposited salt is collected every day or week. This unit aims to prevent brine from releasing into the environment because it is very harmful. In previous models of cascade solar still, no solution has been presented to the problem of brine release from the cascade solar stills. Also, one other aim of this unit is to prevent the deposits of salt in the cascade solar still. All equations presented for the solar still are valid, but enthalpy, specific heat coefficient and viscosity of the brine should be refined in terms of the concentration of salt in saline water. It should be mentioned for the importance of the energy balance in the recycling unit, the confidence intervals of capacity for this unit should be estimated based on the effect of the days with the fewest number of sunlight hours in the year.

In the hours of operation (pick solar hours), the brine entered gradually into the recycling unit totaling about 2 to 3 liters per day. The internal energy of the thin layer of the brine increased and evaporated quickly. The glass cover temperature in the SBSS and cascade solar still are obtained by numerical solution or can be estimated from empirical equations [42]. For determining the glass cover temperature, the average of the temperatures of the glass cover that was reported in the same weather conditions and similar design can be used. Also, the glass cover temperature can be obtained from [42]:

$$
\begin{gathered}
A_{r} h_{w}\left(T_{g}-T_{a}\right)+A_{r} h_{r . g-s}\left(T_{g}-T_{s}\right)=\left[h_{e . w-g}+h_{r . w-g}+\right. \\
\left.h_{c . w-g}\right]\left(T_{w}-T_{g}\right) \\
A_{r}=\frac{A_{g}}{A_{w}}
\end{gathered}
$$

where, $T_{s}$ has been used as the basin (sink) temperature, $A_{g}$ and $A_{w}$ are areas for the glass and water plate, respectively. The hourly yield of single basin solar still is given by [35, 42]:

$$
m_{e w}=\frac{q_{e . w-g i}}{h_{f g}} \times 3600
$$

where, $h_{f g}$ is the latent heat of evaporation $\left(\mathrm{W} / \mathrm{m}^{2} \mathrm{~K}\right)$

$$
h_{f g}=3044205.5-1679.1 T_{w}-1.14
$$

\section{RESULTS AND DISSUASION}

In this research, the performance of a novel hybrid solar still was investigated. For the performance analysis of the hybrid solar still, saline water was used with $35 \mathrm{~g} / \mathrm{kg}$ salt. Results that were obtained according to saline water temperature and other data are in the city of Tabriz in North West Iran on September 9, 2016. Figure 5 shows the variation of ambient temperature based on solar time $(12=$ solar noon $)$. It is seen that the highest temperature is between $12-1 \mathrm{pm}$.

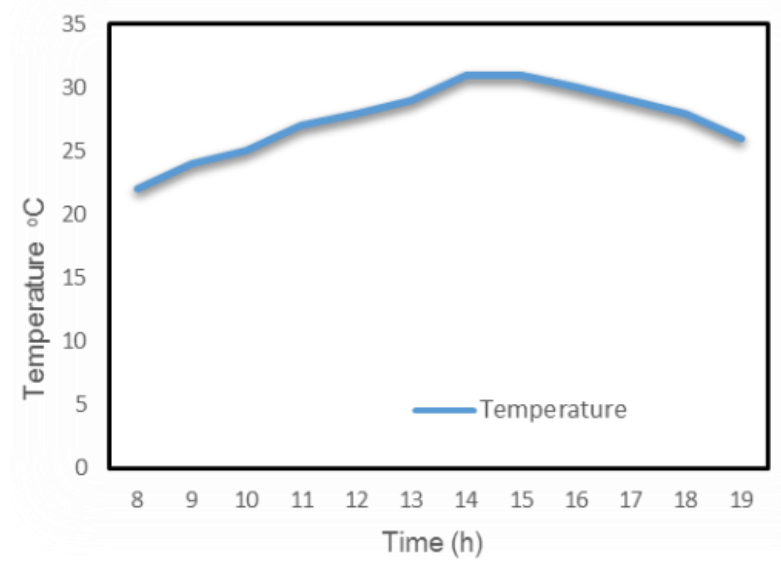

Figure 5. Variation of temperature in test day $(08 / 09 / 2016)$

The outlet temperature of the PTC, cascade solar still, and single basin slope solar still (recycling unit) are presented in Figure 6. It is observed that the temperature of saline water in the system increases by increasing the solar intensity during the day. The average wind speed was about $4 \mathrm{~m} / \mathrm{s}$ at the 
research location. The highest measured temperature belonged to the cascade solar still. The operation of the glass as a condenser is possible when the glass temperature difference with saline water at least $5^{\circ}$ is required. The wind blowing or any coolant agent can increase the internal condensation efficiency, which will increase production. Figure 7 shows the amount of solar radiation on the inclined surface for months. PTC and cascade solar still designed at optimal annual slope. So they receive more energy from single basin still. The highest amount of solar energies is in July and June and the least of them are December and January. Figure 8 presents monthly and annual optimum tilt angle $(\beta)$. The maximum and minimum value of $\beta$ is obtained as $\sim 69^{\circ}$ and $2^{\circ}$ for December and June, respectively. The average annual tilt angle is about $34^{\circ}$ as shown in Figure 8. The slope of the system was selected based on the optimal annual slope. The hourly productivity rate of the cascade solar still and single basin slope solar (SBSS) still are reported in Figure 9. It is clear from the results of Figure 9 that hourly productivity increases with the increase of the solar intensity. The maximum productivity rate hourly approximately occurred between the times $12-13 \mathrm{pm}$ and 13 $14 \mathrm{pm}$.

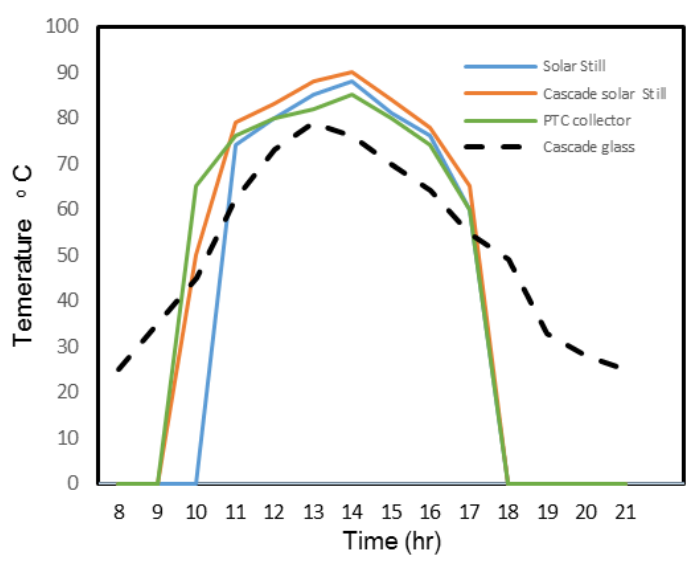

Figure 6. Variation of temperature solar still, cascade solar still, PTC, cascade glass

Average Monthly Radiation ( $\mathrm{MJ} / \mathrm{m}^{\wedge} \mathbf{2}$.Day)

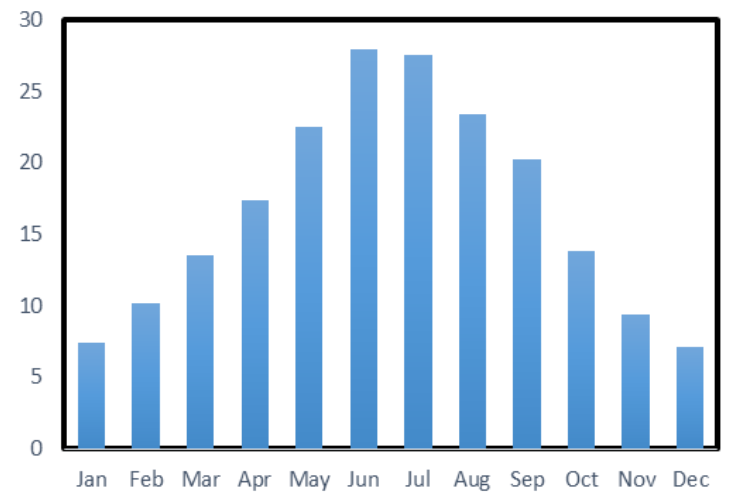

Figure 7. Monthly average of daily total radiation on tilted surface

Insulation of side walls, wind blowing, flow rate, solar energy and temperature difference ambient and saline water are important factors of the production. The same behavior has also been obtained from the analysis of active solar distillation by Kumar and Tiwari (2010) [37], Tripatia and Tiwari (2006)
[46] and Tiwari et al. (2009) [45]. Similar results for cascade solar still have been reported by Tabrizi et al. (2010) $[5,6]$, Velmurugan et al. (2009) [9], Radhwan (2004) [43], Kabeel et al. (2012) [44] and Abdullah (2013) [45]. Figure 9 shows hourly solar intensity variation. The maximum amount of energy that received about $1 \mathrm{~kW} . \mathrm{h} / \mathrm{m}^{2}$. day during the solar noon. It is found from Figure 9 that the average daily solar intensity is about $0.83 \mathrm{~kW} . \mathrm{h} / \mathrm{m}^{2}$. The yield of the cascade solar still was higher than that of SBSS at the same temperatures. In the first two hours of SBSS, it had not any production. The calculations have been done for a nominal capacity of 20 liters of saline water, where 4-5 liters of water was in the static (resting stage) space of the device. Most heat loss occurs from the glass of the cascade solar still and the SBSS. The evaporation and the temperature differences in the glass are necessary for condensation to occur in the cascade solar still or the SBSS. According to the results of studies by Radhawan [33] and Tiwari [34, 29], the temperature difference between the glass temperature and saline water was $5-15^{\circ} \mathrm{C}$. The experimental results revealed that there is a $5-10{ }^{\circ} \mathrm{C}$ temperature difference in the cascade solar still. The experimental results showed $10 \%$ increase in production compared to the dual effect model of Parsad and Tiwari [38], this result therefore shows that the $6 \%$ difference is from performance.

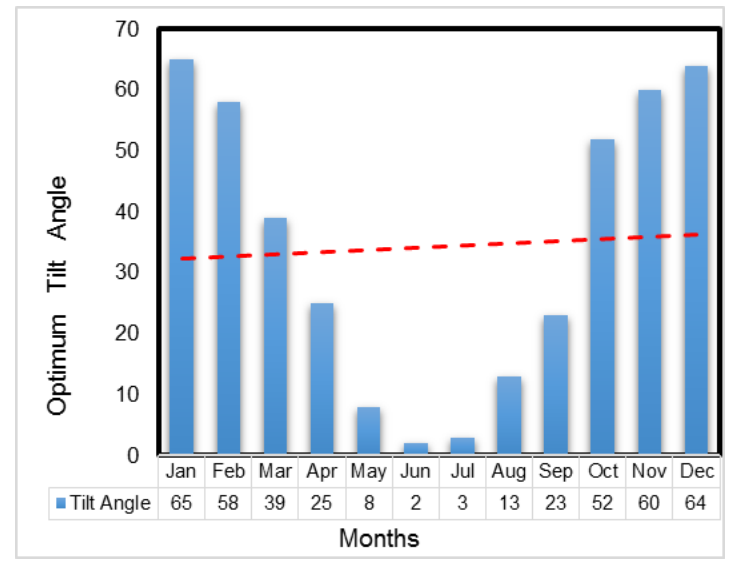

Figure 8. Variation of optimum tilt angle in months

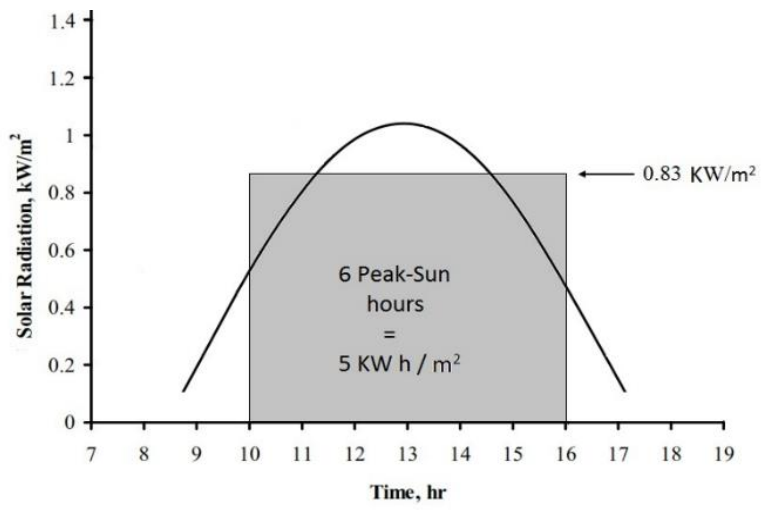

Figure 9. Solar radiation intensity during test day

From 6 hour of peak sunlight for the PTC, 10 percent of the radiation is unavailable because of the direction of the PTC being fixed to the south direction. The effect of mass flow on the outlet temperature of HTF in PTC is calculated in Figure 11. This calculation is based on the rate of Reynolds input of saline water, the temperature at the end of the pipe of PTC 
from the bulk temperature model with constant heat flux and assuming a constant average of heat flow [24, 25]. It is found that the optimal flow rate for the outlet temperature was 70 to $90{ }^{\circ} \mathrm{C}$ which is about 0.001 to $0.005 \mathrm{Kg} / \mathrm{s}$. The flow rate of the system determined based on the investigation from Figure 11. According to Figure 11, by reducing the flow rate to 0.001 $\mathrm{Kg} / \mathrm{s}$, it can be seen that the outlet temperature steeply increases. The same behavior is also reported by Mohamad (2003) [20] and Bouvier et al. (2016) [47]. The effect of heat convection between the tube and saline water (called 'HTF') on the output temperature in PTC is plotted by using EES software shown in Figure 12. It is seen that the optimal heat convection coefficient is about 70 to $200 \mathrm{~W} / \mathrm{m}^{2}$. ${ }^{\circ} \mathrm{C}$; heat convection coefficient (h) depends on the area of PTC and saline water Reynolds. In the present study, experimental productivity rates of a designed model were compared with the results presented by Velmurugan et al. [32, 33 and 34], Tabrizi et al. $[13,11]$ and Tiwari et al. $[37,36]$.

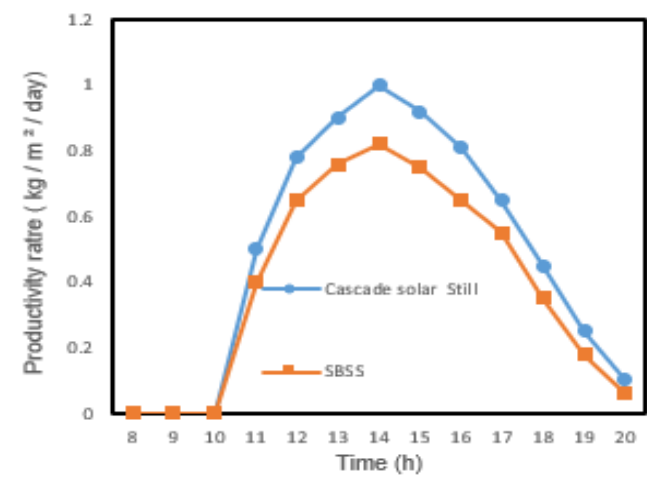

Figure 10. Effect of time on productivity in cascade/solar still

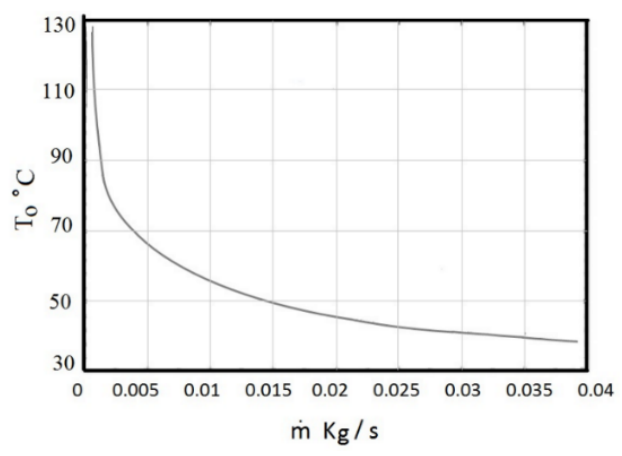

Figure 11. Effect of mass flow on output temperature of HTF in PTC

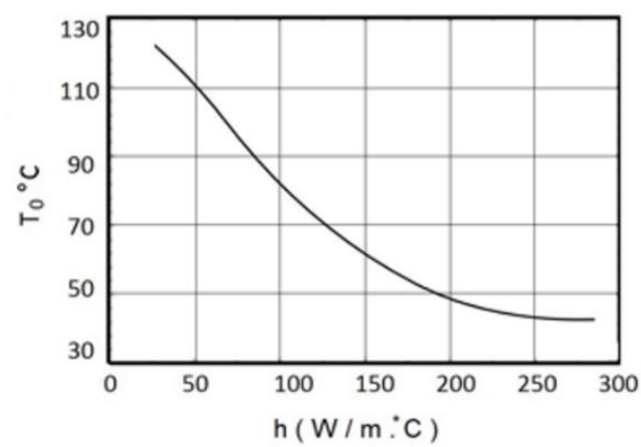

Figure 12. Effect of heat convection on output temperature in PTC
The systems of Tabrizi and Velmurugan were designed based on a cascade solar still model, but Tiwari's system was a combination of SBSS with a flat photovoltaic plate (PV), the results were compared with their results as shown in Figure 13. The most important parameters of each model are as follows: In Tiwari's model, on 13th April 2006, water depth was $0.05 \mathrm{~m}$ the area of the PV was $0.55 \times 1.2 \mathrm{~m}^{2}$, the area of the basin was $1 \mathrm{~m}^{2}$, the wind speed was $1 \mathrm{~ms}-1$ and the solar radiation was 4.6 KW/ $/ \mathrm{m}^{2}$.day. In Velmurugan's model: in May 2007, the area of the cascade solar still was $1 \mathrm{~m}^{2}$, the wind speed was 1 $\mathrm{ms}^{-1}$ and the solar radiation was $4.6 \mathrm{~kW} / \mathrm{m}^{2}$ per day. In Tabrizi's model: on the 23rd of May 2009, the area of the cascade solar still was $1 \mathrm{~m}^{2}$ and the solar intensity was in the range of 578 to $610 \mathrm{~W} / \mathrm{m}^{2}$ per day (solar radiation was approximately $4.4 \mathrm{~kW} / \mathrm{m}^{2}$ per day). The average error of experimental data was measured to be around $7 \%$, regardless of the differences in weather conditions and other environmental and physical conditions, the average error of the experimental data compared with the error of the calculated data was approximately under $5 \%$. Figure 14 presents energy efficiencies versus solar time with solar intensity for the hybrid (active) solar distillation. The efficiency of the system was the highest when the amount of solar radiation reached the maximum amount during the solar noon. Efficiency of The PTC is about $10 \%$ more than the cascade solar still. Similar behavior for active solar distillation systems has also been reported in the studies of Singh et al. [11], Tiwari et al. (2015) [36] and El-Sebabii et al. [7].

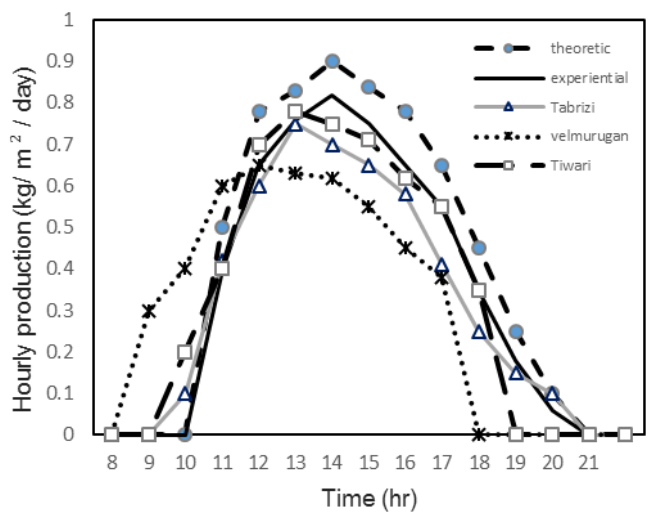

Figure 13. Comparison of experimental productivity rates of the hybrid solar distillation with results presented by Velmurugan et al. [32-34], Tabrizi et al. [12, 13] and Tiwari et al. $[36,37]$

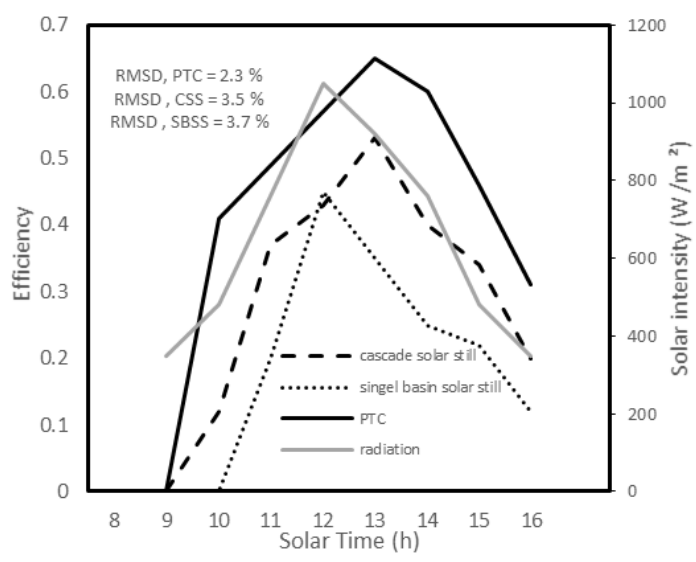

Figure 14. Hourly variation of energy efficiency with solar intensity at cascade /single basin solar still and PTC 
The variation of various heat transfer coefficients $h_{c}$ and $h_{e}$ with $0.001 \mathrm{~kg} / \mathrm{s}$ mass flow for cascade solar still and SBSS in active solar distillation shown in Figure 15. The depth of saline water in the cascade solar still was about $0.4 \mathrm{~cm}$ and for the single basin solar still was about $0.15 \mathrm{~cm}$. The evaporation heat transfer coefficient of single basin solar still was more than that of cascade solar still. It is seen that the effect of the depth has been increased $h_{e}$ for the single basin solar still. The same behavior has also been reported in studies by Tripatia and Tiwari [31, 44], Tiwari et al. [45] for the active solar still and velmurugan et al. [14], for the cascade solar still. It is found that evaporation rate depends on the solar intensity and the depth of saline water in the cascade /single basin solar still. For analysis errors experimental date of efficiency and heat transfer coefficient has been evaluated by root -mean- squaredeviation criterion (RMSD).

$$
\sigma_{R M S D}=\left[\frac{1}{N_{t o t}} \sum_{i=1}^{N_{t o t}}\left(\frac{T_{\text {exp }}-T_{c a l}}{T_{\text {exp }}}\right)_{i}^{2}\right]^{0.5} \times 100
$$

RMSD for efficiency in the experiment for PTC, CSS and SBSS were 2.3, 3.5 and $3.7 \%$, respectively. This analysis shows that RSMD for heat transfer coefficient were 4.3 and $3.1 \%$, respectively.

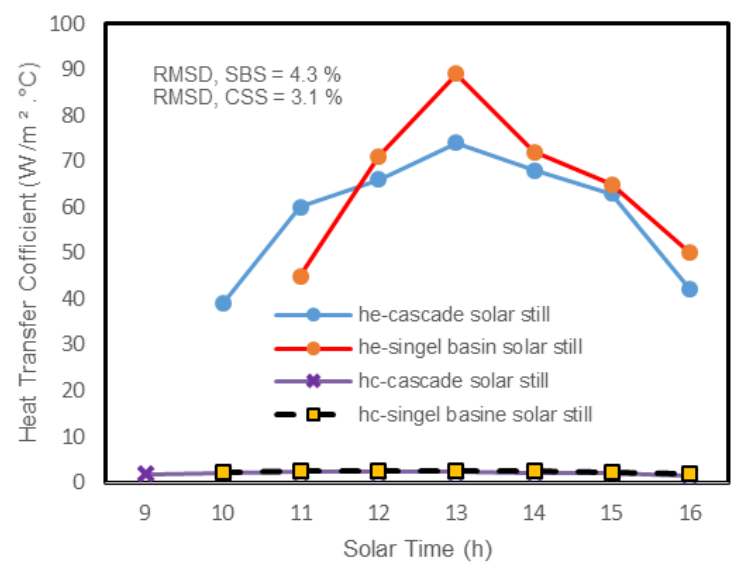

Figure 15. Variation of heat transfer coefficients with 0.001 $\mathrm{Kg} / \mathrm{s}$ mass flow for cascade / single basin solar still in active solar distillation

\section{CONCLUSION}

This study investigates a novel design of a hybrid solar distillation system. The hybrid solar distillation system which was studied in our present research includes a parabolic trough collector (PTC), cascade solar still and single slope single basin solar still as a recycling unit. The system fabricated and experimentally tested during the 6 peak hours of sunlight with saline water (salinity of $35 \mathrm{~g} / \mathrm{kg}$ ). The productivity was about $6.1 \mathrm{Kg} / \mathrm{m}^{2}$.day in the cascade solar still and $4.15 \mathrm{Kg} / \mathrm{m}^{2}$.day for the single basin solar still (recycling unit) with $450 \mathrm{~g}$ of solid salt. The solid salt can be used in the consumption of livestock and industry and causes no environmental problems. The average total efficiency of the hybrid solar distillation reached up to $41 \%$, when the daily average solar radiation was about $5 \mathrm{~kW} . \mathrm{h} / \mathrm{m}^{2}$.day. The average efficiencies for PTC, cascade solar still and single basin solar still were about $50 \%$, $39 \%$ and $27 \%$, respectively; the highest thermal performance and efficiency were obtained at 12 to $13 \mathrm{pm}$ (solar time). The results show $12 \%$ improvement in efficiency for the hybrid solar distillation in comparison with the SBSS systems. The brine recycling removed one of the biggest environmental disadvantages of cascade solar stills. In conclusion this novel hybrid solar distillation presents a suitable model for utilization of the cascade solar stills. To design a cascade solar still site included of parabolic collectors and recycle unite, it is recommended that the units be connected continuously from cascade solar stills so that increase the flow rate. By increasing the flow rate, it will product more internal evaporation in the site without heat loss.

\section{REFERENCES}

[1] Moungar, H., Azzi, A., Youcef, S., Aabdelkrimr, H. (2018). Monthly fresh water yield analysis of three solar desalination units a comparative study in the south Algeria climatic condition. International Journal of Heat and Technology, 36(4): 1330-1335. https://doi.org/10.18280/ijht.360423

[2] Moungar, H., Azzi, A., Youcef, S., Aabdelkrimr, H. (2017). Immersed fins influence on the double slope solar still production in south Algeria climatic condition. International Journal of Heat and Technology, 35(4): 1065-1071. https://doi.org/10.18280/ijht.350444

[3] Sathyamurthy, R., Nagarajan, P.K., Edwin, M., Madhu, B., El-Agouz, S.A., Ahsan, A., Mageshbabu, D. (2016). Experimental investigations on conventional solar still with sand heat energy storage. International Journal of Heat and Technology, 34(4): 97-603. https://doi.org/10.18280/ijht.340407

[4] Badran, O.O., Abu-Khader, M.M. (2007). Evaluating thermal performance of a single slope solar still. Heat and Mass Transfer, Springer, 43(10): 985-995. https://doi.org/10.1007/s00231-006-0180-0

[5] Sadaghiyani, O.K., Boubakran, M.S., Hassanzadeh, A. (2018). Energy and exergy analysis of parabolic trough collectors. Progress in Solar Energy and Engineering Systems, $2(1)$ : $11-20$. https://doi.org/10.18280/PSEES.020103

[6] Tiwari, G.N., Dimri, V., Chel, A. (2009). Parametric study of an active and passive solar distillation system: Energy and exergy analysis. Journal of Desalination, 242 1-18. https://doi.org/10.1016/j.desal.2008.03.027

[7] Narasipuram, R.P., Somu, C., Yadlapalli, R.T., Simhadri, L.S. (2018). Efficiency analysis of maximum power point tracking techniques for photovoltaic systems under variable conditions. Int. J. Innovative Computing and Applications, $\quad 9(4)$ : 230-240. https://doi.org/10.1504/IJICA.2018.095812.

[8] Rajanand Patnaik, N., Ravindranath Tagore, Y. (2016). Design and evaluation of PUC (Packed U Cell) topology at different levels \& loads in terms of THD. In European Journal of Advances in Engineering and Technology, 3(9): https://doi.org/10.1109/AEEICB.2017.7972393

[9] Behar, O., Khellaf, A., Mohammedi, K. (2015). A novel parabolic trough solar collector model - validation with experimental data and comparison to engineering equation. Journal of Energy Convers. Manag, 106: 268281. https://doi.org/10.1016/j.enconman.2015.09.045

[10] Sathyamurthy, R., Nagarajan, P.K., Edwin, M., Madhu, 
B., El-Agouz, S.A., Ahsan, A., Mageshbabu, D. (2016). Experimental investigations on conventional solar still with sand heat energy storage. International Journal of Heat and Technology, 34(4): 597-603. https://doi.org/10.18280/ijht.340407

[11] Norozi, M. (2017). Experimental investigation of improving received radiation by an hourly sun tracking on a weir-type cascade solar still. International Journal of Heat and Technology, 35(4): 737-746. https://doi.org/10.18280/ijht.350407

[12] Tabrizi, F.F., Mohammad, D., Hamid, M. (2010). Experimental investigation of a weir-type cascade solar still with built-in latent heat thermal energy storage system. Journal of Desalination, 260: 248-53. https://doi.org/10.1016/j.desal.2010.03.033

[13] Tabrizi, F.F., Dashtban, M., Hamid, M., Kiyanoosh, R. (2010). Effect of water flow rate on internal heat and mass transfer and daily productivity of a weir-type cascade solar still. Journal of Desalination, 260: 239-47. https://doi.org/10.1016/j.desal.2010.03.037

[14] Velmurguan, V., Naveen, K.H., Srithar, K. (2012). Performance analysis in stepped solar for effluent desalination. Journal of Energy, 34: 1179-1186. https://doi.org/10.1016/j.energy.2009.04.029

[15] Sharqawy, M.H., John, H., Lienhard, V., Zubair, S.M. (2012). Thermophysical properties of seawater: A review of existing correlations and data. Desalination and Water Treatment, 16(1-3): 354-380 https://doi.org/10.5004/dwt.2010.1079

[16] Wang, Y., Liu, Q., Liu, J., Jin, H. (2015). Performance analysis of a parabolic trough solar collector with nonuniform solar flux conditions. Journal of Heat and Mass Transfer, 82:

236-249. https://doi.org/10.1016/j.ijheatmasstransfer.2014.11.055

[17] Liang, H., You, S., Zhang, H. (2015). Comparison of different heat transfer models for parabolic trough solar collectors. Journal of Applied Energy, 148: 105-114. https://doi.org/10.1016/j.apenergy.2015.03.059

[18] Behar, O., Khellaf, A., Mohammedi, K.A. (2015). Novel parabolic trough solar collector model - validation with experimental Eata and comparison to engineering equation solver (EES). Journal of Energy Convers. Manag, 106: 268-281. https://doi.org/10.1016/j.enconman.2015.09.045

[19] Bakos, G.C. (2006). Design and construction of a twoaxis sun tracking system for parabolic trough collector (PTC) efficiency improvement. Journal of Renewable Energy, 31:

2411-2421 https://doi.org/10.1016/j.renene.2005.11.008

[20] Mohamed, A. (2003). Numerical investigation of the dynamic performance of the parabolic trough solar collector using different working fluids. Journal of Port Said Engineering Research, 7(1): 100-115.

[21] Ghasemi, S.E., Mehdizade, A.G.H.R. (2014). Numerical analysis of performance of solar parabolic trough collector with $\mathrm{Cu}$-Water nanofluid. Journal of Nano Dimens, 5: 233-240. https://doi.org/10.7508/ijnd.2014.03.004

[22] Alfellage, M.A.A. (2014). Modeling and experimental investigation of parabolic trough solar collector, thesis for the degree of master in mechanical engineering. Embry-Riddle Aeronautical University, Dayton Beach, Florida.

[23] Coccia, G., Nicola, G.N., Sotte, M. (2015). Design, manufacture, and test of a prototype for a parabolic trough collector for industrial process heat. Renewable Energy, 74: 727-736. https://doi.org/10.1016/j.renene.2014.08.077

[24] Holman, J.P. (2010). Heat Transfer. Tenth Edition, Southern Methodist University, McGraw-Hill.

[25] Incropera, F.P., Bergman, T.L., Lavine, A.S., DeWitt, D.P. (2011). Fundamentals of Heat and Mass Transfer. Seventh Edition, Inc. Willy.

[26] Mohammad, D., Tabrizi, F.F. (2011). Thermal analysis of a weir- type cascade solar still integrated with PCM storage. Journal of Desalination, 279: 415-22. https://doi.org/10.1016/j.desal.2011.06.044

[27] Khosravi, M. (2011). The experimental analysis combining performance cascade solar still method humidification-dehumidification-desalination. Thesis for the degree of Master in University of Sistan and Baluchistan. Iran, Zahedan.

[28] Ziabari, F.B., Sharak, A.Z., Moghadam, H., Tabrizi, F.F. (2013). Theoretical and experimental study of cascade solar stills. Sol. Energy, 90: 205-211. https://doi.org/10.1016/j.solener.2012.12.019

[29] Kumar, M., Tiwari, G.N. (1996). Estimation of convective mass transfer in solar distillation systems. Journal of Sol. Energy, 57(6): 456-464. https://doi.org/10.1016/S0038-092X(96)00122-3

[30] Tripathi, R., Tiwari, G.N. (2005). Effect of water depth on internal heat and mass transfer for active solar distillation. Journal of Desalination, 173: 187-200. https://doi.org/10.1016/j.desal.2004.08.032

[31] Velmurugan, V., Pandiarajan, S., Guruparan, P., Subramanian, H., Prabaharan, D., Srithar, K. (2009). Integrated performance of stepped and single basin solar stills with mini solar pond. Journal of Desalination, 249: 902-909. https://doi.org/10.1016/j.desal.2009.06.070

[32] Velmurugan, V., Mandlin, J., Stalin, B., Srithar, K. (2009). Augmentation of saline streams in solar stills integrating with a mini solar pond. Journal of Desalination, 249: 143-149. https://doi.org/10.1016/j.desal.2009.06.016

[33] Abdulhaiy, M., Radhawan, A.M. (2004). Transient performance of a stepped solar still with built-in latent heat thermal energy storage. Journal of Desalination, 171 61-76. https://doi.org/10.1016/j.desa1.2003.12.010

[34] Elango, C., Gunasekaran, N., Sampathkumar, K. (2015). Thermal models of solar still -A comprehensive review. Journal of Renewable and Sustainable Energy Reviews, 47: 856-911. https://doi.org/10.1016/j.rser.2015.03.054

[35] Tiwari, G.N., Yadav, J.K., Singh, D.B., Al-Helal, I.M., Abdel-Ghany, A.M. (2015). Exergoeconomic and enviroeconomic analyses of partially covered photovoltaic flat plate collector active solar distillation system. Journal of Desalination, 367: 186-196. https://doi.org/10.1016/j.desal.2015.04.010

[36] Kumar, S., Tiwari, G.N. (2010). Design, fabrication and performance of a hybrid photovoltaic thermal $(\mathrm{PV} / \mathrm{T})$ active solar still. Energy Convers. Manag, 51: 1219-1229. https://doi.org/10.1016/j.enconman.2009.12.033

[37] Prasad, B., Tiwari, G.N. (1996). Analysis of double effect solar distillation. Journal of Energy Convers. Manag, 37(11): 1647-1656. https://doi.org/10.1016/0196-8904(95)00359-2

[38] Zoori, H.A., Tabrizi, F.F., Sarhaddi, F., Heshmatnezhad, F. (2013). Comparison between energy and exergy 
efficiencies in a weir type cascade solar still. Journal of Desalination, 325: 113-121. https://doi.org/10.1016/j.desal.2013.07.004

[39] Omara, Z.M., Kabeel, A.E., Younes, M.M. (2013). Enhancing the stepped solar still performance using internal reflectors. Journal of Desalination, 314: 67-72. https://doi.org/10.1016/j.desal.2013.01.007

[40] Tiwari, G.N., Singh, H.N., Tripathi, R. (2003). Present status of solar distillation. Sol. Energy, 75: 367-373. https://doi.org/10.1016/j.solener.2003.07.005

[41] Ghanim, F.M. (2008). Mathematical modeling of A solar still. Thesis for the degree of Master of Energy Engineering in University of Khartoum.

[42] Aybar, H.S. (2006). Mathematical modeling of an inclined solar water distillation system. Journal of Desalination, 190:

63-70. https://doi.org/10.1016/j.desal.2005.07.015

[43] Tripatia, T., Tiwari, G.N. (2006). Thermal modeling of passive and active solar stills for different depths of water by using the concept of solar fraction. Solar Energy, 80: 956-967. https://doi.org/10.1016/j.solener.2005.08.002

[44] Tiwari, G.N., Dimri, V., Chel, A. (2009). Parametric study of an active and passive solar distillation system: Energy and exergy analysis. Desalination, 242: 1-18. https://doi.org/10.1016/j.desal.2008.03.027

[45] Mohamed, A.M., IEl-Minshawy, N.A. (2011). Theoretical investigation of solar humidificationdehumidification desalination system using parabolic trough concentrators. Energy Convers. Manag, 52: 31123119. https://doi.org/10.1016/j.enconman.2011.04.026

[46] Bouvier, J.L., Michaux, G., Salagnac, P., Kientz, T., Rochier, D. (2016). Experimental study of a micro combined heat and power system with a solar parabolic trough collector coupled to a steam Rankine cycle expander. Sol. Energy, 134: 180-192. https://doi.org/10.1016/j.solener.2016.04.028

\section{NOMENCLATURE}

$\begin{array}{ll}\mathrm{A}_{\mathrm{b}} & \text { area of basin, }\left(\mathrm{m}^{2}\right) \\ \mathrm{A}_{\mathrm{g}} & \text { area of glass cover, }\left(\mathrm{m}^{2}\right) \\ \mathrm{Cp} & \text { specific heat capacity }\left(\mathrm{kJ} \cdot \mathrm{kg}^{-1} \cdot \mathrm{K}^{-1}\right) \\ h_{e . w-g} & \text { evaporative heat transfer coefficient from } \\ & \text { water to inner surface of glass }\left(\mathrm{W} \cdot \mathrm{m}^{-2} \mathrm{~K}^{-1}\right) \\ \mathrm{h}_{\mathrm{r}, \mathrm{w}-\mathrm{g}} & \text { radiation heat transfer coefficient from } \\ & \text { water to inner surface of glass }\left(\mathrm{W} \cdot \mathrm{m}^{-2} \mathrm{~K}^{-1}\right) \\ h_{t . g-a} & \text { total loss heat transfer coefficient from glass } \\ \mathrm{k} & \text { to air }\left(\mathrm{W} \cdot \mathrm{m}^{-2} \mathrm{~K}^{-1}\right) \\ \mathrm{Nu} & \text { thermal conductivity, } \mathrm{W} \cdot \mathrm{m}^{-1} \cdot \mathrm{K}^{-1} \\ \mathrm{~T}_{\mathrm{S}} & \text { local Nusselt number along the heat source }\end{array}$

\section{Subscripts}

$\begin{array}{ll}\mathrm{a} & \text { ambient } \\ \mathrm{b} & \text { basin } \\ \mathrm{g} & \text { glass } \\ \mathrm{p} & \text { absorber plate } \\ \mathrm{i} & \text { inlet } \\ \mathrm{r} & \text { receiver } \\ \mathrm{w} & \text { water }\end{array}$

